\title{
Correction to: Real Option Exercise Decisions in Information Technology Investments: a Comment
}

\author{
Josef Schosser ${ }^{1}$ (D)
}

Published online: 4 November 2020

(C) Springer Nature Switzerland AG 2020

\section{Correction to: SN Operations Research Forum https://doi.org/10.1007/s43069-020-00032-1}

The original version of this article unfortunately contained a mistake in the reference section, specifically references 7 and 9. Reference 7 should be changed from "Nau, Robert F, McCardle, Kevin F (1992) Arbitrage, rationality, and equilibrium, Decision making under risk and uncertainty (Durham, NC, 1990), Theory Decis. Lib. Ser. B Math. Statist. Methods, 22 pp 189-199, Kluwer Acad. Publ., Dordrecht" to "Nau RF, McCardle KF (1991) Arbitrage, rationality, and equilibrium. Theory Decis 31(23):199-240". Reference 9 should be changed from "Dybvig PH, Ross SA (1987) Arbitrage. In: Eatwell J, Milgate M, Newman P (eds) The New Palgrave: a dictionary of economics, vol 1, A to D Macmillan Press, London, pp 100-106" to "Dybvig PH, Ross SA (1987) Arbitrage. In: Eatwell J, Milgate M, Newman P (eds) The New Palgrave: a dictionary of economics, vol 1, A to D. Macmillan Press, London, pp 100-106".

The online version of the original article can be found at https://doi.org/10.1007/s43069-020-00032-1

Josef Schosser

josefschosser01@gmail.com

1 University of Passau, 94030 Passau, Germany 